\title{
A Review on Green BIM Potentials in Enhancing the Construction Industry Practice
}

\author{
Noor Akmal Adillah Ismail", Hazwani Ramli, Elma Dewiyana Ismail, Raja Rafidah Raja Muhammad Rooshdi, Shaza \\ Rina Sahamir, and Nur Hidayah Idris
}

Faculty of Achitecture, Planning and Surveying, University Teknologi MARA, Shah Alam, Selangor, Malaysia

\begin{abstract}
The construction industry environment nowadays is becoming more complex with more issues to be resolved with the agreeable approaches amongst the team. Nevertheless, the Building Information Modelling (BIM) innovation is acknowledged to disentangle those prevalent issues towards delivering a better project performance. With the emergence of BIM technology, various concerns such as constant errors and reworks, team-miscommunication, construction waste, energy inefficiencies, and many more in the industry practices, could be refined. Specifically, BIM capabilities mainly facilitate the design and construction operations. Albeit the processes involved demand an early planning and profound decision-making, the BIM mechanism helps the project team to execute the proposed construction projects effectively. With regards to maintaining the sustainability in the industry, "Green BIM" term is introduced to describe the manipulation of BIM technology to be incorporated along with the sustainable design and construction techniques. Therefore, this paper reviews the potentials of "Green BIM" in improving the traditional practices of project stakeholders throughout the project life cycle, particularly focusing on the design and construction phases. It discusses the previous studies on "Green BIM", "Green BIM" concepts, and "Green BIM" approaches concerning its benefits and challenges in enhancing the construction industry practices. Significantly, through the appropriate "Green BIM" resolution, the procedures initiated with the green settings and completed with the green requirements, could empower more sustainable construction industry
\end{abstract}

\section{Introduction}

The "green" construction is increasingly becoming the norm in most new construction project nowadays. Due to its numerous benefits, green construction that promotes sustainability in the construction industry brings altogether the industry stakeholders to join the green building bandwagon. The green project's principles are evolved around developing design and construction conforming towards natural resources usage efficiency including energy, water, material selection, environmental quality, operations and maintenance, and waste and toxic reduction [1]. To make more effective improvement in the construction industry, governments across the globe significantly took initiatives to mandate green standards as for making their construction projects more sustainable against environmental impact. Following the green design and construction trends, the term "Green BIM" comes into the scene, contributing more effects towards sustainability in the construction industry. As portrayed by its name, Green BIM is aforesaid sustainable practice majorly concerning to preserve the construction industry activities to give minimal impacts towards their surroundings and environment via the application of Building Information
Modelling (BIM) technology. The BIM technology itself is defined as an innovation that compiles policies, processes and technologies, constituting a methodology to control construction project design and its data [2] and to digitally coordinate relationships between building objects for construction activities [3]. As internationally reported by NBS (2016), BIM adoption amongst the construction players has increased due to its numerous benefits offered for their building projects, such as cost and time saving, reduced human resource, quality and performance improvement, clash detection, improved accuracy, increased profitability, enhanced collaboration and communication, better presentation and documentation process, improved planning and design, better visualisation and improved information [4].

Realizing the potentials of Green BIM in improving sustainability in the construction industry, many construction players have initiated the Green BIM mechanism in their practices, as recorded by several previous researchers. For example, BIM-based sustainability analysis demonstrates the capabilities of BIM technology in assessing the criteria of BREEAM rating system, provided that all sub-processes are clarified prior to the integration stage [5]. Accordingly,

\footnotetext{
* Corresponding author: noorakmaladillah@gmail.com
} 
as explored by [6], the application of BIM-based approach providing appropriate data in the development of green built environment could facilitate the industry professionals regardless their backgrounds or expertise, in predicting outcomes of minimizing environmental impacts on construction project life-cycle [6]. However, the operation necessitates the tool's identification at the very beginning of the project to decide on the data input and resources required throughout the process so that sustainability goals for the project could be achieved favorably.

Other than that, the methodology of BIM was also seen as a potential to be aligned within frameworks containing the guidelines and standards to promote sustainable development in the built environment [7]. Additionally, in the UK construction industry, a case study exploited the integration of Framework for Sustainable Strategic Development (FSSD) and BIM in enhancing strategies, policies and leadership towards sustainable production, to be aligned with Modern Method of Construction (MMC) [8]. In the UK elsewhere, a study was conducted to develop BIM execution planning for sustainable design process model to assist the construction industry stakeholders with critical decisions actions towards more effective project delivery [9]. Moreover, in New Zealand, BIM implementation has been broadly regulated with the aspiration of Green Star rating in shifting its construction industry towards more environmentally and economically sustainable practice [10]. Nevertheless, the number of practitioners involved was relatively small due to challenges associated with the processes of Green Star and BIM application.

Other studies are concentrating on using BIM capabilities to improve existing building energy modelling (BEM) practices [11], optimizing energy consumption in building design with BIM [12], and BIM sustainable indicators towards construction cost estimate preparation [13]. With most of the previous researchers discussing the potentials of using BIM towards more sustainable construction industry, therefore, this paper reviews the benefits and challenges associated with the practice. Previous studies underlying Green BIM and green BIM concepts are also explained to obtain more perspectives on Green BIM approach.

\section{Methods}

This paper is a review paper that primarily obtained its sources from relevant established journal articles, conference papers, books and others. The contents assessed were enclosed to the main subject of Green BIM encompassing; (1) the previous studies to observe the progress and current implementation of Green BIM approach; (2) Green BIM concepts that interpret the doctrine of green and sustainable design and construction, BIM fundamentals on its digitalized models to improve visualization and coordination in building design and construction, and the combination of both green sustainable building and BIM technology to intensify the processes; and (3) the mechanism of Green
BIM to cultivate better performance in construction industry practices concerning the benefits offered and also the challenges that need to be overcome to ensure the sustainability in the industry is progressively developed. Hence, the keywords used to search associated information for this paper essentially epitomize "Green BIM", sustainable design and construction", "sustainability in the construction industry", "sustainable BIM", and further combinations of those. This paper was also regulated to refine the information search within five to six years references in certifying that only updated data are accommodated for the potential readers. Yet, it was exceptional for certain information in any sources that contain viewpoints related to fundamentals, principles and concepts defining "Green BIM" as a whole. The preferable information was ultimately presented in this paper result and discussion sections recapitulating the sub-topics of Green BIM previous studies, Green BIM concepts, and the benefits and challenges of Green BIM approach in improving the construction industry practices.

\section{Results and discussion}

The results and discussion in this paper acknowledge the previous studies undertaken by other researchers on the topics linked with Green BIM, expounds Green BIM concepts and identifies benefits and challenges with respect to Green BIM implementation.

\subsection{Previous studies on Green BIM}

Many of previous researchers have addressed Green BIM elements in their studies. The issues accentuated are mostly on how Green BIM could more efficiently benefit design and building performance specifically in dealing with environmental impacts, as compared to the application of traditional approaches. Table 1 below briefly explains the highlights of those studies.

Table 1. Previous studies on Green BIM.

\begin{tabular}{|l|l|}
\hline Author (Year) & \multicolumn{1}{|c|}{ Highlights } \\
\hline$[14]$ & $\begin{array}{l}\text { Highlights the BIM benefits in } \\
\text { improving design and building } \\
\text { performance towards sustainability } \\
\text { through the information delivery } \\
\text { process; significantly for integrated } \\
\text { project delivery (IPD) and design } \\
\text { optimization [14]. }\end{array}$ \\
\hline$[15]$ & $\begin{array}{l}\text { Presents a methodology conforming } \\
\text { BIM and LCA tools towards designing } \\
\text { sustainable building projects that } \\
\text { develop information database via a } \\
\text { model to simplify the process of } \\
\text { creating sustainable designs and to } \\
\text { evaluate the environmental impacts } \\
\text { (EI) of buildings [15]. }\end{array}$ \\
\hline
\end{tabular}




\begin{tabular}{|c|c|}
\hline$[23]$ & $\begin{array}{l}\text { Suggests a BIM-based building design } \\
\text { optimization method improve building } \\
\text { sustainability; in which a case study } \\
\text { was conducted to integrate BIM-based } \\
\text { simulation system and PSO-based } \\
\text { optimization system, in comparison } \\
\text { with traditional methods, considering } \\
\text { multi-objective problems [16]. }\end{array}$ \\
\hline [17] & $\begin{array}{l}\text { Presents the BIM usage as an effective } \\
\text { tool to integrate natural and technical } \\
\text { systems in architectural design; a case } \\
\text { study was adopted where multi- } \\
\text { dimensional digital models were used } \\
\text { for multidisciplinary project } \\
\text { coordination to explore green design } \\
\text { principles accorded with BIM } \\
\text { technology for sustainable } \\
\text { infrastructures [17]. }\end{array}$ \\
\hline$[18]$ & $\begin{array}{l}\text { Examines the feasibility of using 3D } \\
\text { simulation transfer processes to } \\
\text { streamline the environmental } \\
\text { assessment of buildings that have been } \\
\text { designed digitally using building } \\
\text { information modelling (BIM); where } \\
\text { key credits in LEED can be integrated } \\
\text { within the BIM design process to } \\
\text { tackle environmental design issues in } \\
\text { meeting sustainable criteria [18]. }\end{array}$ \\
\hline [19] & $\begin{array}{l}\text { Develops a green template for life } \\
\text { cycle assessment of buildings based on } \\
\text { BIM focusing on embodied } \\
\text { environmental impact; to improve } \\
\text { existing evaluation techniques having } \\
\text { data incompatibilities and time- } \\
\text { consuming data conversion issues [19]. }\end{array}$ \\
\hline$[20]$ & $\begin{array}{l}\text { Reviews } 96 \text { papers related to building } \\
\text { energy efficiency and suggests } \\
\text { engagement of an Integrated } \\
\text { Knowledge-based } \\
\text { Management System using nD BIM } \\
\text { applications (BIM-IKBMS) during the } \\
\text { post-construction building lifecycle to } \\
\text { advance the successful implementation } \\
\text { of sustainable building performances } \\
\text { [20]. }\end{array}$ \\
\hline$[21]$ & $\begin{array}{l}\text { Reviews criteria concerning social and } \\
\text { cultural sustainability to be } \\
\text { incorporated within a green BIM } \\
\text { framework to be served as a basis for } \\
\text { performance evaluation to enhance } \\
\text { existing guidelines and standards; } \\
\text { therefore, allowing sustainable } \\
\text { sociocultural benefit from green } \\
\text { building projects [21]. }\end{array}$ \\
\hline$[22]$ & $\begin{array}{l}\text { Applies the theory of Life Cycle } \\
\text { Assessment (LCA) and BIM } \\
\text { mechanism to survey the current } \\
\text { developments in the energy efficiency } \\
\text { of structural systems; focusing on } \\
\text { decision-making procedures within } \\
\text { BIM systems including optimisation } \\
\text { methods, buildability and safety } \\
\text { constraints and code compliance } \\
\text { limitations [22]. }\end{array}$ \\
\hline
\end{tabular}

\begin{tabular}{|l|l|} 
[23] & $\begin{array}{l}\text { Demonstrates the potentials and } \\
\text { deficits of the modelling, analysis and } \\
\text { optimisation of energy-efficient } \\
\text { industrial buildings using BIM to BEM } \\
\text { methodology, through two industrial } \\
\text { facilities case studies; in which a BIM } \\
\text { for BEM workflow for design and } \\
\text { optimisation of industrial facilities was } \\
\text { assessed [23]. }\end{array}$ \\
\hline
\end{tabular}

\subsection{Green BIM concepts}

The concepts of "Green BIM" are commonly used to describe sustainable building design and construction incorporating the usage of BIM technology. In general, sustainable development principles entangle the environmental aspect concerning resources usage, economic aspect involving the ability to support economic production, and social aspect establishing systems to function at a social well-being level [24]. Correspondingly, [1] defines building green as ways of using resources such as energy, water, materials, and land than conventional buildings or buildings that are typically built to the latest codes, more efficiently [1]. Whilst, green or sustainable building is characterized as "high performance building", in which green strategies could minimize or mitigate environmental impact towards land use, building design, construction and operation. Green buildings objective is to increase efficiency of natural resources utilization in concurrent with diminishing adverse impact on the environment. Hence, the construction project team should be responsible for designing and constructing buildings that are energy efficient, use natural or reclaimed materials, concerning the surroundings they endure [1]. Whereas, BIM, as comprehensively defined by Eastman et al. (2011) is a modelling technology associated with processes to produce, communicate and analyzed building model that describes building components as digital representations to establish coordinated data [25]. Therefore, integrating BIM mechanism with the green or sustainable building could mean adapting an advanced technology with digital models as references, to faciliate controlling environmental effects on building design, construction and operation resulting from its immense activities, towards achieving more intelligent and efficient ways of practising sustainability in the construction industry.

\subsection{The Green BIM implementation benefits}

BIM existence in the construction industry offers numerous benefits peculiarly in improving team performance and productivity due to the usage of coordinated digital models to reduce errors and reworks. The application of the technology subsequently establishes more effective communication and collaboration within the team. Additionally, more reliable decision-making would be constituted, hence accomplishing more successful project goals. With regards to merits gained in virtue of Green BIM 
implementation, it can be observed through several aspects. [1] emphasized the benefits of procuring green building economically could maximize cost savings, increase productivity, and escalate property values and marketability. Other than that, the indirect benefits are improved image, risk reduction, future proofing, and self-reliance.

Elsewhere, [22] reiterated that Green BIM approach has great advantages when enforced during early design development of buildings, in which it could result in less cost and more effective work processes within the engineering and sustainable energy domains [22]. As exemplified by [16] building design optimization employing BIM platform to improve sustainability is much better as compared to the traditional design method. The BIM technology could facilitate the project team to produce building life-cycle analysis, concerning such thermal and lighting systems and their interaction to establish results approaching real situations. The BIMintegrated procedures conducted could then reduce errors and reworks, therefore attaining optimal design faster and easier. Highlighted by [20] the BIM adoption is also valuable in minimizing energy consumption during the post-construction phase in comparison when using conventional CAD method. 3-nd BIM models permit rich information to be integrated and structured characterizing visualization, informatization, standardization and collaboration towards building sustainability essentials.

Furthermore, [23] explored the potentials of BIM in modelling, analysis and optimization of energy-efficient industrial buildings. Adopted BIM to BEM methodology, they found that the integration of both modelling processes would identify BEM requirements earlier, where coordination of models examines uncertainties at the very beginning of the building design to optimize building performance analysis. Whilst, [18] scrutinized the possibility of LEED evaluation within the BIM process, proving that the integration between LEED key credits and BIM technology could tackle crucial environmental design issues, accordingly aligning building elements and sustainability criteria. The LEED conjoined BIM operation also encouraged a faster assessment approach as compared to traditional method.

\subsection{The challenges of Green BIM practices}

Despite the advantages acquired from Green BIM practices, there are also some challenges that demand solutions to envisage all-embracing sustainable construction. [1] suggests that the significant challenges involve both conceptual and practical when inculcating green measuring and performance criteria. Conceptually, the term of "performance" needs to be determined and understood precisely in conjunction with several distinguished principles: (1) as-built building characteristics; (2) building upgrades, renovations and reconfigurations; and (3) environmental results and consequences of sustainable strategies. Whereas, practically, the challenges are evolved around actual and modeled performance, in which preferences in exploiting relevant data are confounding in between using models or estimations to reflect operating and design performance.

Since many of the construction industry players do not acknowledge the real benefits of green buildings due to insuffiecient education towards building sustainability, the Green BIM awareness remains obvilious [1]. As presumed by [20], the study conducted reveals that the lack of experts amongst industry players has caused BIM application not discipline-oriented enough, thus disallowing the extended usage of BIM for energy conservation to promote energy efficiency in buildings. There is a great lack of well-educated and trained BIM professionals, therefore more training are needed to verify the future development of BIM in sustainable building design and construction [14].

[18] also identified challenges of using BIM for environmental assessment related to software complexity issues. Although it is possible to accommodate BIM into LEED evaluation, the incompatibility between the different software used for the BIM models to align with sustainable analysis always become the major problem. Consequently, limited information is developed by the digital models, hence, the restriction occurred brings the manual assessment method to replace the BIM application. Furthermore, the cost barrier associated with original building design and construction always becomes the consideration in upholding the entire building life [1].

\section{Conclusions}

Preserving sustainability in the construction industry could lead towards a more vigorous built environment. Green BIM as one of the sustainable development platforms conceivably could assist towards accomplishing the sustainability goals. There are lots of advantages gained by the construction players when integrating BIM into their green and sustainable building projects. The advantages include reducing errors and reworks due to digital models' coordination, accelerating conventional processes hence saving time and cost, encouraging more effective communication and collaboration within project teams, and many more. Nonetheless, despite benefits gained from the execution of Green BIM in the construction industry practices, there are also some challenges that need to be addressed along with the implementation process. For instance, the costs for the additional software, compatibility issues in transferring data between different operating systems, the unfamiliarity of users with the software program employment, and so on. To fully utilize the Green BIM merits, the implementation must be properly planned and designed according to the objectives of the proposed projects, concurrently depreciating the barriers that might disrupt the progress. Undoubtedly, more efforts are needed from the implementers especially when dealing with digital models and its appropriate data, so that Green BIM mechanism will only add significant values towards improving their project performance. Therefore, the application of software and its federated 
models in Green BIM operation must be articulated with the skills and knowledge of deploying the technology from the users themselves.

\section{References}

1. S. Kubba, Handbook of Green Building Design and Construction, 2nd ed. ButterworthHeinemann, (2016)

2. B. Succar, Building information modelling framework: A research and delivery foundation for industry stakeholders, Autom. Constr., vol. 18, no. 3, pp. 357-375, (2009)

3. C. Egbu and P. Coates, Building Information Modelling (BIM) implementation and remote construction projects: Issues, challenges and critiques, J. Inf. Technol. Constr., vol. 17, pp. 75-92, (2012)

4. NBS, International BIM Report 2016, (2016)

5. M. A. Zanni, R. Soetanto, and K. Ruikar, Exploring The Potential Of BIM-Integrated Sustainability Assessment In AEC, in Sustainable Building Conference 2013, pp. 186195 (2013)

6. A. Z. Sheth and S. M. Malsane, Building Information Modelling, a tool for green built environment, in All India Seminar on Innovation in Green Building Technology, Green Build 2014, (2014)

7. H.-Y. Chong and X. Wang, The outlook of building information modeling for sustainable development, Clean Technol. Environ. Policy, vol. 18, no. 6, SI, pp. 1877-1887 (2016)

8. Z. Alwan, P. Jones, and P. Holgate, Strategic sustainable development in the UK construction industry, through the framework for strategic sustainable development, using Building Information Modelling, J. Clean. Prod., vol. 140, pp. 349-358 (2017)

9. M.-A. Zanni, R. Soetanto, and K. Ruikar, Defining the sustainable building design process: methods for BIM execution planning in the UK, Int. J. Energy Sect. Manag., vol. 8 no. 4 pp. 562-587 (2014)

10. A. GhaffarianHoseini, D. Tien Doan, N. Naismith, J. Tookey, and A. GhaffarianHoseini, Amplifying the practicality of contemporary building information modelling (BIM) implementations for New Zealand green building certification (Green Star), Eng. Constr. Archit. Manag., vol. 24 no. 4 pp. 696-714 (2017)

11. T. Gerrish, K. Ruikar, M. Cook, M. Johnson, and M. Phillip, "Using BIM capabilities to improve existing building energy modelling practices, Eng. Constr. Archit. Manag., vol. 24 no. 2 pp. 190-208 (2017)

12. S. Egwunatum, E. Joseph-Akwara, and R. Akaigwe, Optimizing Energy Consumption in
Building Designs Using Building Information Model (BIM), Slovak J. Civ. Eng., vol. 24 no. 3 pp. 19-28 (2016)

13. N. Akmal, A. Ismail, N. H. Idris, H. Ramli, and S. Rina, Sustainable BIM-Based Cost Estimating for Quantity Surveyors Sustainable BIM-Based Cost Estimating for Quantity Surveyors, vol. 63 pp. 235-240, (2018)

14. K. Wong and Q. Fan, Building information modelling (BIM) for sustainable building design, Facilities, vol. 31 no. $3 / 4$ pp. 138-157 (2013)

15. F. Jalaei and A. Jrade, Integrating Building Information Modeling (BIM) and energy analysis tools with green building certification system to conceptually design sustainable buildings, J. Inf. Technol. Constr., vol. 19 pp. 494-519 2014.

16. S. Liu, X. Meng, and C. Tam, Building information modeling based building design optimization for sustainability, Energy Build., vol. 105 pp. 139-153 (2015)

17. W. Bonenberg and X. Wei, Green BIM in Sustainable Infrastructure, Procedia Manuf., vol. 3 pp. 1654-1659 (2015)

18. Z. Alwan, D. Greenwood, and B. Gledson, Rapid LEED evaluation performed with BIM based sustainability analysis on a virtual construction project, Constr. Innov., vol. 15 no. 2 pp. 134150 (2015)

19. S. Lee, S. Tae, S. Roh, and T. Kim, Green template for life cycle assessment of buildings based on building information modeling: Focus on embodied environmental impact, Sustain., vol. 7 no. 12 pp. 16498-16512 (2015)

20. A. Ghaffarianhoseini et al., Building Information Modelling (BIM) uptake: Clear benefits, understanding its implementation, risks and challenges, Renew. Sustain. Energy Rev. (2016)

21. I. Reychav, R. Maskil Leitan, and R. McHaney, Sociocultural sustainability in green building information modeling, Clean Technol. Environ. Policy, vol. 19 no. 9 pp. 2245-2254 (2017)

22. S. Eleftheriadis, D. Mumovic, and P. Greening, Life cycle energy efficiency in building structures: A review of current developments and future outlooks based on BIM capabilities, Renew. Sustain. Energy Rev., vol. 67 pp. 811825 (2017)

23. G. Gourlis and I. Kovacic, Building Information Modelling for analysis of energy efficient industrial buildings - A case study, Renew. Sustain. Energy Rev., vol. 68 pp. 953-963 (2017)

24. G. H. Brundtland, Report of the World Commission on Environment and Development: Our Common Future, (1987)

25. C. Eastman, P. Teicholz, R. Sacks, and K. Liston, BIM handbook, 1st ed. Hoboken, NJ: 
Wiley, (2011) 